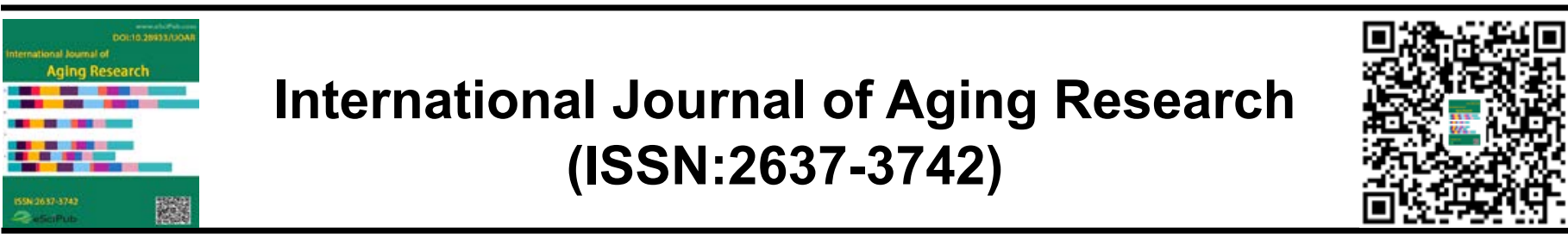

\title{
INTEGRATIVE REVIEW STUDY: FACTORES RELATED TO METABOLIC SYNDROME IN THE ELDERLY
}

\section{Ana Cláudia Cavalcante da Silva ${ }^{1 *}$, Analucia de Lucena Torres ${ }^{2}$, Luana Bertoldo Freitas de Andrade $^{3}$, Mariana Carolini Oliveira Faustino ${ }^{4}$, Mariana Isabel Alexandre Moura ${ }^{5}$, Thayse Andressa Nascimento Silva ${ }^{6}$}

${ }^{1}$ UFPE; ${ }^{2}$ UFPE; ${ }^{3}$ UFPE; ${ }^{4}$ UFPE; ${ }^{5}$ UFPE; ${ }^{6}$ UFPE.

\begin{tabular}{|c|c|}
\hline \multirow[b]{2}{*}{$\begin{array}{l}\text { troduction: Metabolic Syndrome (MS) is a set of pathological } \\
\text { Ad physiological changes, defined by pre-established parame- } \\
\text { rs, such as dyslipidemia, central adiposity, arterial hypertension } \\
\text { Ad diabetes. Objective: To identify the scientific production of } \\
\text { ssociated cardiovascular risk factors in elderly patients with MS. } \\
\text { lethodology: This is an integrative review of the literature ob- } \\
\text { ined by searching scientific articles in the LILACS, MEDLINE, } \\
\text { CIELO and BDENF databases, by crossing the descriptors } \\
\text { letabolic X Syndrome, Aged and Risk Factors. Inclusion criteria } \\
\text { ere articles that had a summary available online, published in } \\
\text { e period from } 2013 \text { to } 2017 \text {, focusing on the proposed theme. } \\
\text { eview articles, books, book chapters, opinion articles, editorials, } \\
\text { ssertations, theses, programs and government reports were } \\
\text { xcluded, and } 8 \text { articles were selected. Results: The findings } \\
\text { רowed that the regular practice of physical activity associated } \\
\text { ith a diet rich in fruits, vegetables and whole grains contributes } \\
\text { the metabolic syndrome control. In addition to other important } \\
\text { ctors such as the diagnostic criteria that may vary according to } \\
\text { e severity of MS. The criteria were established from some as- } \\
\text { xciations that work with the theme such as: National Cholester- } \\
\text { Education Program/Adults Treatment Panel - NCEP - ATP III } \\
\text { TPIII) and International Diabetes Federtion (IDF), the first most } \\
\text { sed because it is not necessary to evaluate insulin resistance, } \\
\text { us making it more viable for the development of research. Con- } \\
\text { usion: The study showed that there is a lack of knowledge re- } \\
\text { arding MS, since there are few organs that treat and study this } \\
\text { oblem, thus reflecting on the search for research on this topic, }\end{array}$} & \\
\hline & $\begin{array}{l}\text { How to cite this article: } \\
\text { Ana Cláudia Cavalcante da Silva, } \\
\text { Analucia de Lucena Torres, Lua- } \\
\text { na Bertoldo Freitas de Andrade, } \\
\text { Mariana Carolini Oliveira Faustino, } \\
\text { Mariana Isabel Alexandre Mou- } \\
\text { ra, Thayse Andressa Nascimento } \\
\text { Silva. INTEGRATIVE REVIEW } \\
\text { STUDY: FACTORES RELATED TO } \\
\text { METABOLIC SYNDROME IN THE } \\
\text { ELDERLY. International Journal of } \\
\text { Aging Research, 2020, 3:58 }\end{array}$ \\
\hline
\end{tabular}




\section{INTRODUCTION}

Over the years, the profile of the world's population has undergone a series of transformations, thanks to technological and socioeconomic advances and the new formulation of the age pyramid ${ }^{5}$. The sedentary, unregulated and malnourished lifestyle that this generation leads has generated the increasingly early onset of chronic diseases, such as cardiovascular diseases or type II diabetes mellitus ${ }^{7}$. In this context, if we take into account the rapid aging of the population, there is an even greater concern that would be the planning of public policies and the direction of multiprofessional teams to meet the moment of demand in the health system ${ }^{1}$. Aging is a natural process of life and involves several neuronal, structural, functional and chemical changes.

These changes in the human body result in inherent characteristics of the aging process, such as: fat accumulation, calcification and degeneration of coronary valves, increased blood pressure, increased gastric emptying time, which interferes with the time of drug absorption and decline in immune function ${ }^{3,2}$. From these changes the elderly becomes more susceptible to the appearance of chronic diseases, especially metabolic syndrome that generates cardiovascular diseases, which cause higher mortality in the population8. Metabolic Syndrome is a set of pathological and physiological changes, such as dyslipidemia obesity, hypertension and diabetes that will increase the risk of cardiovascular diseases ${ }^{2}$. Insulin resistance, a triggering factor of this process, is developed by weight gain or related to type 27 diabetes. The most common cause is weight gain, which consequently leads to increased blood pressure, the development of type 2 diabetes, and changes in triglycerides and cholesterol. There is a difficulty in diagnosing and treating metabolic syndrome, and especially in stimulating patients to fight the disease, because besides being a new expression it is little known, especially in the elderly population. However, in order to identify the main factors that generate such comorbidity, one should associate them with those that lead to weight gain, such as excessive carbohydrate and saturated fat intake, sedentary lifestyle, smoking, in addition to considering the family history of heart problems ${ }^{7}$.

The aging process is demarcated by several physiological changes that contribute to the development of precursor alterations of the Metabolic Syndrome (MS), such as, for example: deposition of abdominal fat, alteration in both lipid and glycemic levels and, mainly, high pressure levels ${ }^{3}$. Associated with this, metabolic MS aggregates several risk factors for the triggering of cardiovascular diseases, such as obesity or overweight, sedentarism, smoking, hypertriglyceridemia, dyslipidemia, Systemic Arterial Hypertension (SAH), hypercholesterolemia, Diabetes mellitus type II (DM II) or insulin resistance, which demonstrate great impact on the appearance of $\mathrm{MS}^{6,2}$. Given the increasing number of cardiovascular disease cases related to metabolic disorder, the need for measures to treat this public health problem becomes evident ${ }^{1}$.

The early identification of this syndrome has become increasingly necessary in order to delay and prevent comorbidities linked to this pathology, especially in the elderly, a group that usually have multiple pathologies due to lack of health prevention. To develop effective care and encourage the implementation of public policies that work to raise awareness of a healthy lifestyle ${ }^{1,4}$. Thus, nursing care that should be provided according to health priorities systematically and recorded in line with the health information system of the service from a standardized language through a classification system ${ }^{1,8}$. Thus, to promote and prevent health in relation to metabolic syndrome is to emphasize the importance of lifestyle change, through the practice of physical exercises and food re-education cooperate significantly for the prevention of this syndrome ${ }^{1,4}$.

\section{OBJECTIVE}


To analyze the elaboration of scientific studies in relation to cardiovascular risk factors associated with elderly patients with metabolic syndrome.

\section{METHODOLOGY}

This study is an integrative literature review, a method that promotes the analysis and synthesis, in an ordered manner, of the results obtained on a topic. Therefore, it allows the formation of conclusions about a certain content and, thus, better use of the evidence found in the studies under study9. The steps for its development were based on the formulation of the problem, delimitation on the literature search, evaluation and analysis of data, presentation and interpretation of results 10 . Data collection was performed in July and
August 2019 through the online search for articles that answered the following research question: What are the risk factors associated with MS in the elderly? Thus, the integrative literature review was obtained by searching for scientific articles in the LILACS, MEDLINE, SCIELO and BDENF databases, using the crossing of the descriptors Metabolic $X$ Syndrome, Elderly and Risk Factors. Regarding the inclusion criteria, it was established articles that had abstract available online, published in the period from 2009 to 2019 , focusing on the proposed theme and, target audience, the elderly. Review articles, books, book chapters, opinion articles, editorials, dissertations, theses, programs and government reports were excluded. Therefore, 14 articles were selected.

\section{Table 1: Description of the scientific articles that addressed the study objectives.}

\begin{tabular}{|c|c|c|c|}
\hline Author & Year & Title & Goal \\
\hline $\begin{array}{l}\text { Elix NDC, Nobrega } \\
\text { MML. }\end{array}$ & 2019 & $\begin{array}{l}\text { Metabolic syndrome: conceptual analysis in } \\
\text { the context of nursing. }\end{array}$ & $\begin{array}{l}\text { To analyze the concept metabolic syndrome } \\
\text { and identify its essential attributes, } \\
\text { antecedents and consequences in the nursing } \\
\text { context. }\end{array}$ \\
\hline 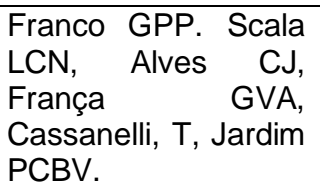 & 2009 & $\begin{array}{l}\text { Metabolic syndrome in hypertensive patients } \\
\text { from Cuiabá - MT: prevalence and } \\
\text { associated factors. }\end{array}$ & $\begin{array}{l}\text { To estimate the prevalence of MS and } \\
\text { associated factors in a sample of hypertensive } \\
\text { patients from the urban area of Cuiabá - MT. }\end{array}$ \\
\hline $\begin{array}{l}\text { Nascimento, JPS et } \\
\text { al. }\end{array}$ & 2015 & $\begin{array}{l}\text { Factors associated with metabolic syndrome } \\
\text { in the elderly: an integrative review. }\end{array}$ & $\begin{array}{l}\text { To identify risk factors associated with } \\
\text { Metabolic Syndrome in the elderly, through an } \\
\text { integrative review, performed in the LILACS, } \\
\text { MEDLINE and BDENF databases, from } 2003 \\
\text { to } 2013 \text {. }\end{array}$ \\
\hline $\begin{array}{ll}\text { Penteado } & \text { FR, } \\
\text { Gomes NM. } & \end{array}$ & 2008 & $\begin{array}{l}\text { Physical activity and metabolic syndrome: a } \\
\text { review study. Digital magazine. }\end{array}$ & $\begin{array}{l}\text { It sought, from a bibliographic survey, to gather } \\
\text { general information about the Metabolic } \\
\text { Syndrome, including its relationship with the } \\
\text { practice of physical activities. }\end{array}$ \\
\hline $\begin{array}{ll}\text { Penteado } & \text { FR, } \\
\text { Gomes NM. }\end{array}$ & 2011 & $\begin{array}{l}\text { Prevalence of metabolic syndrome and its } \\
\text { associated factors in rural Minas Gerais. }\end{array}$ & $\begin{array}{l}\text { To estimate the prevalence of metabolic } \\
\text { syndrome (MS) and its associated factors in } \\
\text { rural Minas Gerais. }\end{array}$ \\
\hline $\begin{array}{l}\text { Ricci GPI, Tomassoni } \\
\text { D, Sirignano A, } \\
\text { Grappasonni I. }\end{array}$ & 2017 & $\begin{array}{l}\text { Metabolic syndrome, hypertension, and } \\
\text { nervous system injury: Epidemiological } \\
\text { correlates. }\end{array}$ & $\begin{array}{l}\text { To analyze medico-social aspects related to } \\
\text { MS, considering the reduction of work capacity } \\
\text { and the disability condition that it involves. }\end{array}$ \\
\hline Silva AO. & 2015 & $\begin{array}{l}\text { Association of aging with insulin resistance, } \\
\text { metabolic syndrome and sarcopenic obesity: } \\
\text { investigation of inflammatory, metabolic } \\
\text { parameters and body composition. }\end{array}$ & $\begin{array}{l}\text { To verify the association of aging with insulin } \\
\text { resistance, metabolic syndrome and } \\
\text { sarcopenic obesity. }\end{array}$ \\
\hline Soares LM. & 2016 & $\begin{array}{l}\text { Lipid accumulation product: accuracy for } \\
\text { identification of patients with metabolic } \\
\text { syndrome in adults. }\end{array}$ & $\begin{array}{l}\text { To evaluate the ability of the Lipid } \\
\text { Accumulation Product (LAP) Index to identify } \\
\text { individuals with Metabolic Syndrome (MS) } \\
\text { diagnosed through different definitions. }\end{array}$ \\
\hline $\begin{array}{l}\text { Souza MT, Silva, MD, } \\
\text { Carvalho R. }\end{array}$ & 2010 & Integrative review: what it is and how to do it. & $\begin{array}{l}\text { To present the constituent phases of an } \\
\text { integrative review and the relevant aspects to } \\
\text { be considered for the use of this } \\
\text { methodological resource. }\end{array}$ \\
\hline Crossetti MGO. & 2012 & $\begin{array}{l}\text { Integrative Review of Nursing Research the } \\
\text { scientific rigor required of it. }\end{array}$ & Inform what is integrative review. \\
\hline
\end{tabular}




\section{RESULTS}

The present abstract was performed after the survey of articles in the databases: LILACS, MEDLINE, SCIELO and BDENF searching for articles published for a maximum of 10 years, with the following descriptors: 1) Metabolic syndrome; 2) Aged; 3) Risk factors. The inclusion criteria for the search were: complete articles online and available for access. Those excluded were those limited to the study in nonage populations, articles with a publication date of less than 2009 and articles that were repeated or that did not fit the objective of the study, even entering the search through the descriptors. In total, 62 articles were retrieved, and of these, 23 with a publication date of less than 2009. At the end, 10 articles were selected to compose the expanded abstract of the integrative review, read and analyzed in full. They were examined as to the nationality and region of the study, the method and the relationship with the theme in question, seeking to deepen the association between the epidemiological characteristics of metabolic syndrome.

MS is defined as the association of several pathophysiological changes, which can be reflected in metabolic disorders that directly perpetuate in the quality of life of the elderly, through the emergence of associated chronic conditions $^{1}$. It is evident that there is a consortium of MS with obesity, overweight, high $\mathrm{BMI}$ and/or altered abdominal circumference, as well as the literature indicates that these are shown as risk factors for cardiovascular impairment ${ }^{2}$. In consonance, excess abdominal fat and reduced muscle mass are predisposing to the development of insulin resistance ${ }^{4,7}$, and are identified as risk factors for $\mathrm{MS}^{5}$. In addition, through the theoretical framework used, it was identified that there is an extensive variation in the prevalence of MS in the elderly, which is intrinsically associated with the criteria used for diagnosis, as well as the ethnic and regional characteristics of the population studied, due to the profile of this population ${ }^{5}$. Thus, MS emerges as a public health problem that requires planning based on the investment of public policies, with the direction of multiprofessional teams, which demand care and increased accessibility of this population to the health system ${ }^{3}$. The findings showed that the regular practice of physical activity associated with a diet rich in fruits, vegetables and whole grains contributes to the metabolic syndrome control. In addition to other important factors such as diagnostic criteria that may vary according to the severity of $\mathrm{MS}^{4}$. The criteria were established from some associations that work with the theme such as: National Cholesterol Education Program/Adults Treatment Panel - NCEP - ATP III (ATPIII) and International Diabetes Federtion (IDF), being the first most used because it does not need to evaluate insulin resistance, thus making it more viable to conduct research.

\section{CONCLUSION}

With the study, it was evidenced the existence of a knowledge gap in relation to MS, since there are few organs that treat and study this problem, thus reflecting in the search for research with this theme, because the subject is little discussed, especially in the elderly. In this perspective, the following were identified as risk associations for the development of MS: socioeconomic factors; age group; self-assessment/self-health perception; history of chronic disease; and irregular physical exercise. Thus, a high prevalence of MS in the elderly was found, making health care to this patient essential, from the identification and early control of risk factors for injury, in order to promote the effectiveness of care in MS.

\section{REFERENCES}

1. Elix NDC, Nobrega MML. Síndrome metabólica: análise conceitual no contexto da enfermagem. Rev. Latino-Am. Enfermagem. 2019; v. (27): 3154.

2. Franco GPP. Scala LCN, Alves CJ, França GVA, Cassanelli, T, Jardim PCBV. Síndrome metabólica em hipertensos de Cuiabá - MT: prevalência e fatores associados. Arquivos Brasileiros de Cardiologia. 2009; v. 92(6): 472478.

3. Nascimento, JPS et al. Fatores associados à síndrome metabólica em idosos: uma revisão 
Ana Cláudia Cavalcante da Silva et al., IJOAR, 2020 3:58

integrativa. Revista Kairós Gerontologia. 2015; v.

(18): 283-297.

4. Penteado FR, Gomes NM. Atividade física e síndrome metabólica: um estudo de revisão. Revista Digital. 2008; v. 13 (125).

5. Pimenta $A M$, Gazzinelli $A$, Velásquez-Meléndez G. Prevalência da síndrome metabólica e seus fatores associados em área rural de Minas Gerais. Ciência \& Saúde Coletiva. 2011; v. 16(7): 3297-3306.

6. Ricci GPI, Tomassoni D, Sirignano A, Grappasonni I. Metabolic syndrome, hypertension, and nervous system injury: Epidemiological correlates. Clin Exp Hypertens. 2017; p. 10.

7. Silva AO. Associação do envelhecimento com a resistência insulínica, síndrome metabólica e obesidade sarcopênica: investigação de parâmetros inflamatórios, metabólicos e composição corporal. Brasília: Dissertação (Mestrado em Educação Física) - Universidade Católica de Brasília; 2015.

8. Soares LM. Produto de acumulação lipídica: acurácia para identificação de portadores da síndrome metabólica em adultos.Biblioteca $\mathrm{J}$ Baeta Vianna. 2016; p. 12 .

9. Souza MT, Silva, MD, Carvalho R. Revisão integrativa: o que é e como fazer. Einstein. 2010; v.

8(1): 102-106.

10. Crossetti MGO. Revisão Integrativa de Pesquisa na Enfermagem o rigor científico que lhe é exigido. Revista Gaúcha de Enfermagem. 2012; v. $33(2): 8-9$.

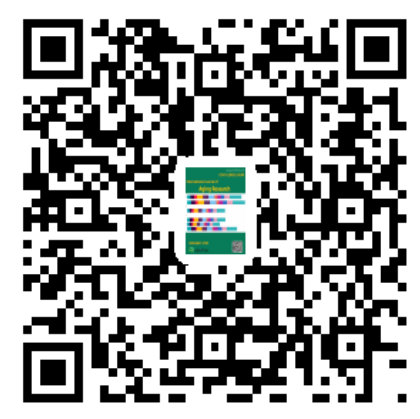

